\title{
Cinegeo
}

International Journal of Environment and Geoinformatics (IJEGEO) is an international, multidisciplinary, peer reviewed, open access journal.

\section{Spatio-Temporal Assessment of Biodiversity Habitat Loss and Fragmentation at Gugu Mountain Ranges, SE Ethiopia}

\section{Demissie Tsega MALLIE, Kefelegn Getahun CHERNET, Tesfaye Debela DUGUMA}

\author{
Chief in Editor \\ Prof. Dr. Cem Gazioğlu \\ Co-Editors \\ Prof. Dr. Dursun Zafer Şeker, Prof. Dr. Şinasi Kaya, \\ Prof. Dr. Ayşegül Tanık and Assist. Prof. Dr. Volkan Demir
}

Editorial Committee (April 2020)

\begin{abstract}
Assos. Prof. Dr. Abdullah Aksu (TR), Assit. Prof. Dr. Uğur Algancı (TR), Prof. Dr. Bedri Alpar (TR), Prof. Dr. Lale Balas (TR), Prof. Dr. Levent Bat (TR), Prof. Dr. Paul Bates (UK), İrşad Bayırhan (TR), Prof. Dr. Bülent Bayram (TR), Prof. Dr. Luis M. Botana (ES), Prof. Dr. Nuray Çağlar (TR), Prof. Dr. Sukanta Dash (IN), Dr. Soofia T. Elias (UK), Prof. Dr. A. Evren Erginal (TR), Assoc. Prof. Dr. Cüneyt Erenoğlu (TR), Dr. Dieter Fritsch (DE), Assos. Prof. Dr. Çiğdem Göksel (TR), Prof.Dr. Lena Halounova (CZ), Prof. Dr. Manik Kalubarme (IN), Dr. Hakan Kaya (TR), Assist. Prof. Dr. Serkan Kükrer (TR), Assoc. Prof. Dr. Maged Marghany (MY), Prof. Dr. Michael Meadows (ZA), Prof. Dr. Nebiye Musaoğlu (TR), Prof. Dr. Erhan Mutlu (TR), Prof. Dr. Masafumi Nakagawa (JP), Prof. Dr. Hasan Özdemir (TR), Prof. Dr. Chryssy Potsiou (GR), Prof. Dr. Erol Sarı (TR), Prof. Dr. Maria Paradiso (IT), Prof. Dr. Petros Patias (GR), Prof. Dr. Elif Sertel (TR), Prof. Dr. Nüket Sivri (TR), Prof. Dr. Füsun Balık Şanlı (TR), Prof. Dr. Uğur Şanlı (TR), Duygu Ülker (TR), Assoc. Prof. Dr. Oral Yağcı (TR), Prof. Dr. Seyfettin Taş (TR), Assoc. Prof. Dr. Ömer Suat Taşkın (US), Dr. İnese Varna (LV), Dr. Petra Visser (NL), Prof. Dr. Selma Ünlü (TR), Assoc. Prof. Dr. İ. Noyan Yilmaz (AU), Prof. Dr. Murat Yakar (TR), Assit. Prof. Dr. Sibel Zeki (TR)
\end{abstract}

\footnotetext{
Abstracting and Indexing: TR DIZIN, DOAJ, Index Copernicus, OAJI, Scientific Indexing Services, International Scientific Indexing, Journal Factor, Google Scholar, Ulrich's Periodicals Directory, WorldCat, DRJI, ResearchBib, SOBIAD
} 


\title{
Spatio-Temporal Assessment of Biodiversity Habitat Loss and Fragmentation at Gugu Mountain Ranges, SE Ethiopia
}

\author{
Demissie Tsega Mallie $^{1, *}$ (iD), Kefelegn Getahun Chernet ${ }^{2}$, Tesfaye Debela Duguma ${ }^{3}$
}

\author{
${ }^{1}$ Jimma University, Department of Geography and Environmental Studies, Jimma, Ethiopia. \\ ${ }^{2} \mathrm{Ph} . \mathrm{D}$, Jimma University, Department of Geography and Environmental Studies, Jimma, Ethiopia \\ ${ }^{3}$ Assistant professor, Jimma University, Department of Geography and Environmental Studies, Jimma, Ethiopia \\ * Corresponding author: D.T. Mallie \\ E-mail: tsdemissie@gmail.com

How to cite: Mallie et al., (2020). Spatio-Temporal Assessment of Biodiversity Habitat Loss and Fragmentation at Gugu Mountain Ranges, SE Ethiopia, International Journal of Environment and Geoinformatics (IJEGEO), 7(1): 54-63. DOI: 10.30897/ijegeo.624488

\begin{abstract}
This study was aimed at assessing afro-alpine and sub-afro-alpine biodiversity habitat loss and fragmentation of Gugu Mountain Ranges using geospatial techniques. Satellite imageries, key informants and field observation were the major sources of data. The land sat images of 1989, 2001 and 2019 were used to compute change and fragmentation level. ERDAS IMAGINE 2014, ArcGIS 10.4 and FRAGSTAT version 4.2 was used to process data. Image differencing (extent and rate of change), normalized difference vegetation index (NDVI), and area, shape, and aggregation metrics were used to analyze the data. The findings showed that a decline in greenness value and shrinking of afro-alpine and sub-afro-alpine habitat by $1.49 \%$ between 1989 and 2001, and 2.62\% between 2001 and 2019. Due to this, the total area covered declined from 3540.65 to 1846.98 hectares over the last 30 years. Moreover, the result further revealed that not only decline in size but also there were habitat fragmentations in the study area.
\end{abstract}

Keywords: Biodiversity, Geospatial Techniques, Gugu Mountain Ranges, Habitat Fragmentation, Habitat Loss

\section{Introduction}

Ethiopia is a relatively vast country with a wide variety of topography and climate. There is a great variation in altitude, ranging from 116 meters below sea level in the Danakil depression to 4620 meters above sea level at the top of Mount Ras Dashen (Hurni et al. 2010; Ministry of Agriculture 2000, Hurni 1995; Kedirgan, 2019). Although much of the interior of Ethiopia is dominated by highland plateaus, all of which are home to numerous endemic species of flora and fauna. There are ecosystems that range from afro-alpine at the highest elevations to desert and semi-desert ecosystems at the lowest elevations (Ethiopian Biodiversity Institute 2015, 2014, Institute of Biodiversity Conservation 2012).

The highlands of Ethiopia, which are widely covered by Afro-alpine moorlands and grasslands, were highly victims of degradation (Woldeamlak 2002, Badege 2001). Largely altered regions of the highlands for centuries and their alarming rate of change have endangered the original species richness of areas. The extinction of many biodiversity in vast regions has been connected with habitat loss and fragmentations caused by land use land cover change (Michelsen and Lindmer 2015), direct exploitation and introduced species (Gaston and Spicer 2004), and mismanagement, settlement, deforestation and budget constraints (Solomon and Dereje 2015).

The fragile environments of the afro-alpine and subafroalpine ecosystems seek much more attention to halt further threat and rate of destruction (Ethiopia Panel on Climate Change, 2015). Similarly, Gugu Mountain Ranges (GMR) is under serious challenge habitat loss and fragmentation. Since geospatial techniques helps to study biodiversity in different dimensions (e.g. Roy and Gorji et al., 2019; Gazioğlu, 2018; Srivasta 2012, Roy 2011, Foody 2008, Tchouto et al. 2006, Salem 2003, Roy and Behera 2002, Roy and Tomar 2000), we utilized geospatial techniques with FRAGSTAT software to assess the magnitude of the problem in the study area. Hence, the ultimate aim of this study was to identify afro-alpine and sub-afro-alpine biodiversity habitat loss and fragmentation.

\section{Materials and Methods}

\section{Description of the Study Area}

The study area is located in Arsi zone at the intersection of Guna, Gololcha and Chole districts. In terms of absolute location, it extends from $8005^{\text {'North to }}$ $8020^{\prime}$ North and 39050'East to 40005'East (Figure 1). The study area possesses an altitude that extends 3575 meters above mean sea level. It covers more than 11,355 hectares.

\section{Sources of Data}

The major data sources for this study were satellite images of different years downloaded from glovis.usgs.gov (Table 1), key informants and field observation. Satellite imageries were obtained from glovis.usgs.gov to trace changes that have been observed in the last thirty years. 




Figure 1: Location of the Study Area in South East Ethiopia

Table 1: Information about satellite images used

\begin{tabular}{llll}
\hline Satellite & Date & Resolution & Download \\
\hline Landsat 8 -OLI & $01 / 02 / 2019$ & $30 \mathrm{mX30m}$ & LC08_L1TP_167054_20190210_20190222_01_T1 \\
Landsat 5-TM & $25 / 12 / 2001$ & $30 \mathrm{mX} 30 \mathrm{~m}$ & LT05_L1TP_167054_20011225_20180918_01_T1 \\
Landsat 5-TM & $23 / 02 / 1989$ & $30 \mathrm{mX30m}$ & LT05_L1TP_167054_19890223_20171214_01_T1
\end{tabular}

Source: glovis.usgs.gov.

Table 2: NDVI Classification

\begin{tabular}{ll}
\hline Class & NDVI \\
\hline No vegetation & $<0$ \\
Lowest dense vegetation & 0 to 0.15 \\
Lower dense vegetation & 0.15 to 0.3 \\
Dense vegetation & 0.3 to 0.45 \\
Higher dense vegetation & 0.45 to 0.6 \\
Highest dense vegetation & $>0.6$ \\
\hline
\end{tabular}

Source: Zaitanuh et al. 2018

Method of Data Analysis

Land Use Land Cover (LULC) Change Analysis Image classification

For this study, a supervised image classification technique based on maximum likelihood algorithm was used. Maximum likelihood algorithm in effect models the probability distributions for each class, using training data, from which it is possible to estimate the likelihood that a given pixel belongs to a particular class (Rees 2001). This helps to make most probable assignment and probability threshold can be imposed (Rees 2001, Malczewski 1999). 
Six classes were utilized to estimate land use land cover of the study area. Thus, it was classified into afro-alpine and sub-afro-alpine, upper afro-montane, swamps, grazing/fallow/open areas, settlement and farmland. In the study site, farmers are using grazing land, fallow and open forest regions interchangeably. Particularly, fallowed lands were done either to secure tenure or due to demarcation of farm plots toward forest region. As a result, grazing, fallow and open lands were coined together.

\section{Change Detection}

Change in the amount of Afro-alpine and Sub-afroalpine ecosystem was generated using the following formula (equation 1). Image differencing involves subtraction of the first date image from a second date image, pixel by pixel (Minu and Shetty 2015).

Total LULCC in hectares $=$ Area final year-Area $_{\text {initial year }}$

(Eq.1.)

The rate of change of land use land cover change was computed using Puyravaud (2003) standardized formula (equation 2).

Rate of LULCC $=\frac{1}{t 2-t 1} X \ln \frac{A 2}{A 1}$

Where t1-Final year LUCC; t2-Initial year LUCC; lnnatural logarithms; A2-area of category in recent time and A1-area of the category at initial year.

Normalized difference vegetation index (NDVI) was also computed to check differences happened in the selected years (equation 3). According to Holme et al (1987) NDVI values can show the vegetation of a given area by differentiating from that of bare soil due to absorption of visible light and reflection of near infrared. Finally, NDVI values were categorized into six for making analysis (Table 2).
$\mathrm{NDVI}=\frac{N I R-R E D}{N I R+R E D}$

Where NDVI-is normalized difference vegetation index, NIR-Near infrared, and RED-red infrared.

\section{Accuracy Assessment}

Prior classifications, for accuracy assessment 25 and 100 reference points for swampy area and for each of other classes respectively were taken. Then, the Kappa Index of Agreement was utilized to decide level of accuracy (Viera and Garrett 2005).

\section{Fragmentation Analysis}

In their response to the Fletcher et al (2018) critics on the finding of Fahrig (2017), Fahrig et al. (2019) indicated that fragmentation control for habitat amount is neither generally good nor generally bad for biodiversity. Fahrig (2003) suggested that fragmentation should be limited to breaking apart of habitat. For her, fragmentation has no consistently negative effects on biodiversity like habitat loss. And, she finally summarized habitat fragmentation as changes in habitat configuration that result from the breaking apart of habitat, independent of habitat loss (Fahrig 2003).

Before Fahrig (2003) conceptualization of habitat fragmentation, Franklin et al. defined it as "the discontinuity resulting from a given set of mechanisms, in the spatial distribution of resources and conditions present in the area at a given scale that affects occupancy, reproduction, or survival in a particular species" (Franklin et al. 2009). As a result, habitat fragmentation is the mixture of habitat and non-habitat. In this study, we are looking fragmentation as a challenge to biodiversity due to the fact that fragmentation increase isolation of patches and decline of species and disruption of ecosystem processes (Fletcher et al. 2018, Millhouser and Singer 2018, Munir et al. 2018, Ibanez et al. 2017, Fuller et al. 2015, Flaspohler et al. 2010, Broadbent et al. 2008). .

Table 3: Land use land cover (LULC)

\begin{tabular}{lllllll}
\hline LULC type & $\mathbf{1 9 8 9}$ & \multicolumn{3}{c}{$\mathbf{2 0 0 1}$} & $\mathbf{2 0 1 9}$ & A \\
\cline { 2 - 7 } & Area (ha) & $\%$ & Area (ha) & \% & Area (ha) & \% \\
\hline UAV & 2099.61 & 18.49 & 2735.1 & 24.09 & 2113.61 & 18.61 \\
AV & 3540.63 & 31.18 & 2961.72 & 26.08 & 1846.98 & 16.27 \\
Sw & 110.88 & 0.98 & 42.48 & 0.37 & 17.775 & 0.16 \\
GFO & 2000.55 & 17.62 & 125.63 & 1.12 & 2785.68 & 24.53 \\
F & 2615.49 & 23.03 & 4024.78 & 35.44 & 2998.51 & 26.41 \\
St & 988.2 & 8.70 & 1465.65 & 12.91 & 1592.8 & 14.03 \\
Total & 11355.36 & 100 & 11355.36 & 100 & 11355.36 & 100
\end{tabular}

UAV-Upper Afro-montane Vegetation; AV-Afro-alpine and sub-afroalpine vegetation; Sw-Swamps; GFO-Grazing/Fallow/Open areas; F-Farmlands; St-Settlement.

Table 4: Statistical computation of NDVI values

\begin{tabular}{llll}
\hline Computed statistics & NDVI_1989 & NDVI_2001 & NDVI_2019 \\
\hline Minimum & 0.10 & 0.00 & 0.03 \\
Maximum & 0.69 & 0.74 & 0.54 \\
Mean & 0.29 & 0.37 & 0.29 \\
Standard deviation & 0.23 & 0.22 & 0.15 \\
\hline
\end{tabular}




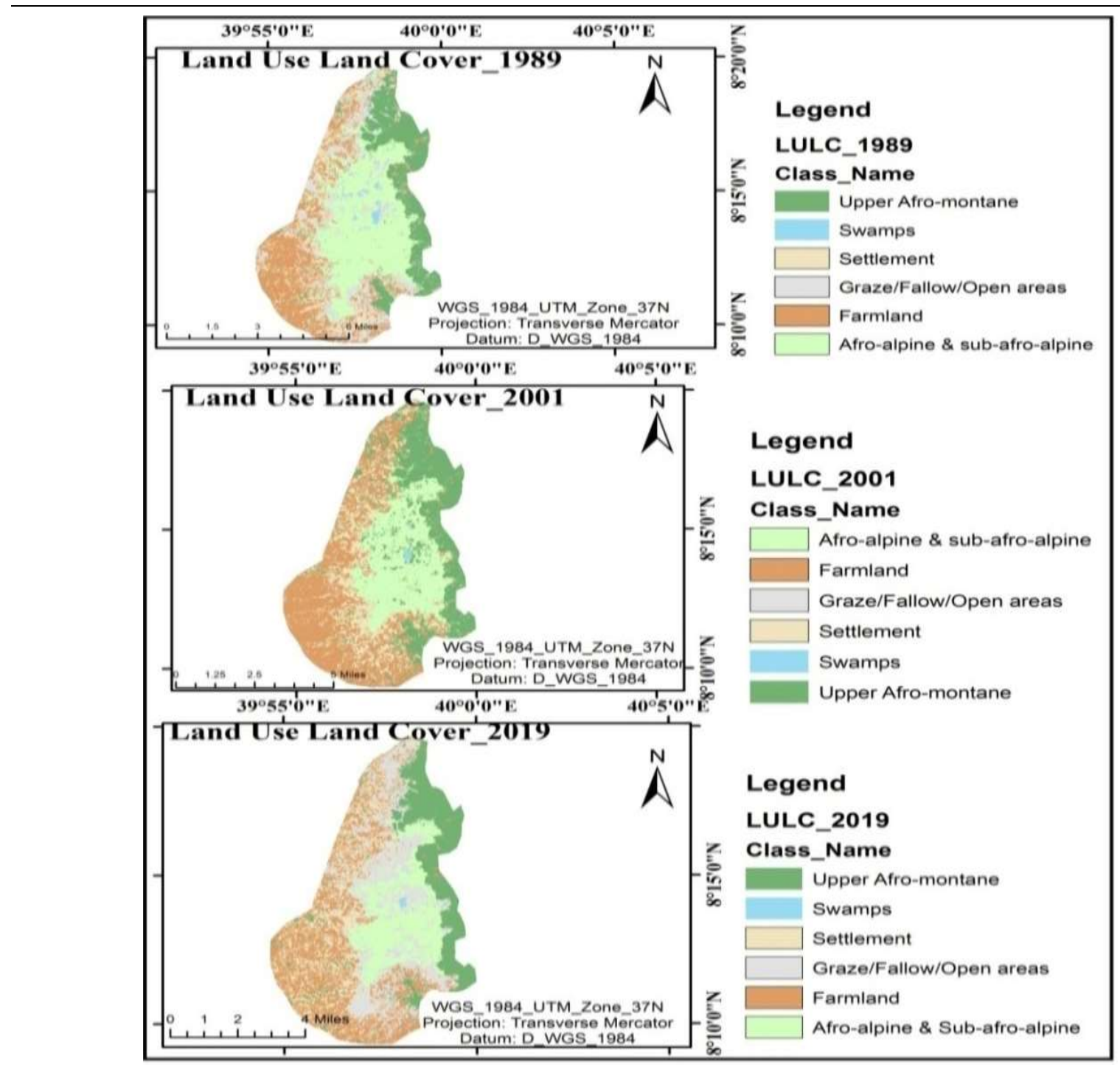

Figure 2: Land use land cover of 1989, 2001 and 2019

According to Wang et al. (2014), there is no perfect metrics for habitat fragmentation analysis but used under certain conditions and biological questions. Due to this, authors computed area, perimeter, largest patch index, edge index, shape index, fractal dimension index, percentage of like adjacencies, interspersion and juxtaposition index, patch cohesion index, splitting index and aggregation index to analyze fragmentation took place at study site. Therefore, classified images were converted to polygon to adjust the projection and reconverted to raster after reclassification, and exported to FRAGSTAT 4.2.1 for these area, shape and aggregation metric computation.

\section{Results \\ Land Use Land Cover Categories}

Landsat images of 1989, 2001 and 2019 were classified into classes using ERDAS imagine 2014. The reclassifications of classified images were also done using ArcGIS10.3. Thus, classes were afro-alpine and sub-afro-alpine, upper afro-montane, swamps, grazing/fallow/open areas, settlement and farmland (see Figure 2) and their coverage was presented on table 3In 1989 afro-alpine and sub-afro-alpine vegetation was covering larger parts of the study area $(31.18 \%)$ and followed by farmland $(23.03 \%)$ and upper afro-montane vegetation (18.49). The remaining parts were covered by grazing/fallow/open areas $(17.62 \%)$, settlement $(8.7 \%)$ and swamps $(0.98 \%)$. Likewise, in 2001 majority of the study area was farmland (35.44\%) and the remaining were classified as afro-alpine vegetation (26.08\%), upper afro-montane vegetation $(24.09 \%)$, settlement $(12.91 \%)$, grazing/fallow/open areas (1.12\%) and swamps (0.37\%). Currently, in 2019, the proportion of classes in the study area showed that farmland (26.41\%), grazing/fallow/open areas $(24.53 \%)$, upper afro-montane vegetation $(18.61 \%)$, afro-alpine vegetation $(16.27 \%)$, settlement (14.03\%) and swamps (0.16\%) (table 3).

\section{Trends of Land Use Land Cover Change from 1989} to 2019

Afro-alpine and sub-afro-alpine vegetation and swamps cover were declined from 1989 to 2019. Settlement areas were increased in the three cover situations. But, farmland and upper Afro-montane vegetation cover were showing increment from 1989 to 2001 but decreased from 2001 to 2019. On the other hand, grazing/fallow/open areas was greatly reduced from 1989 to 2001 and vastly amplified from 2001 to 2019 . 
Hence, farmland, settlement and grazing/fallow/open areas were expanded at the costs of afro-alpine and sub-

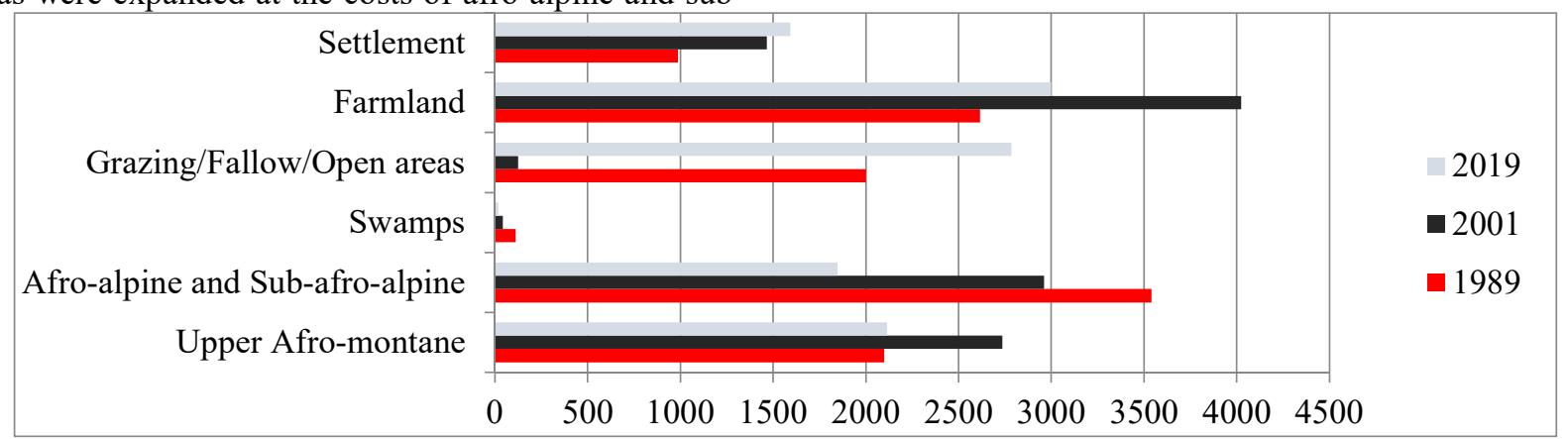

Figure 3: Land use land cover trend from 1989 to 2019.

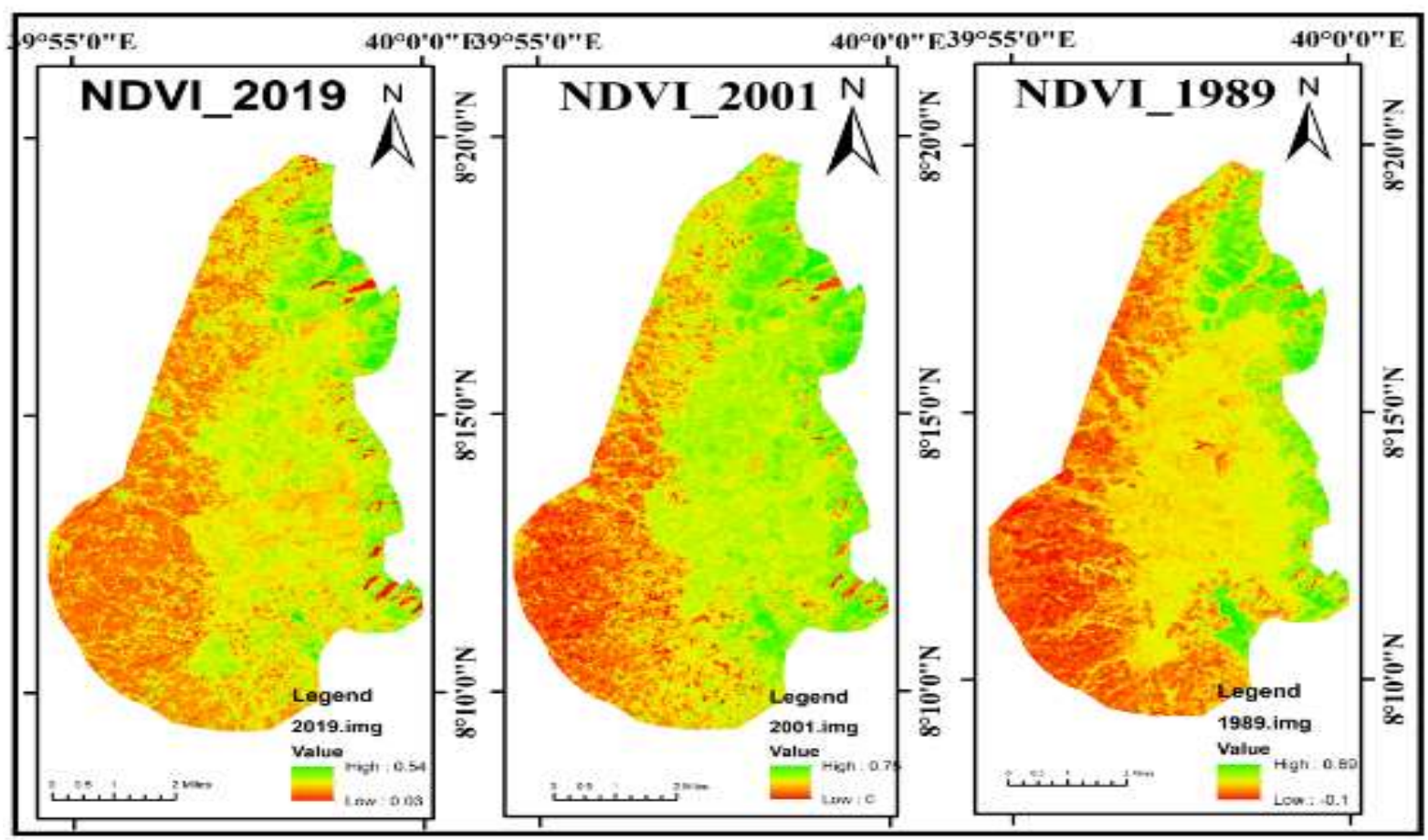

Figure 4: NDVI values of 1989, 2001 and 2019.

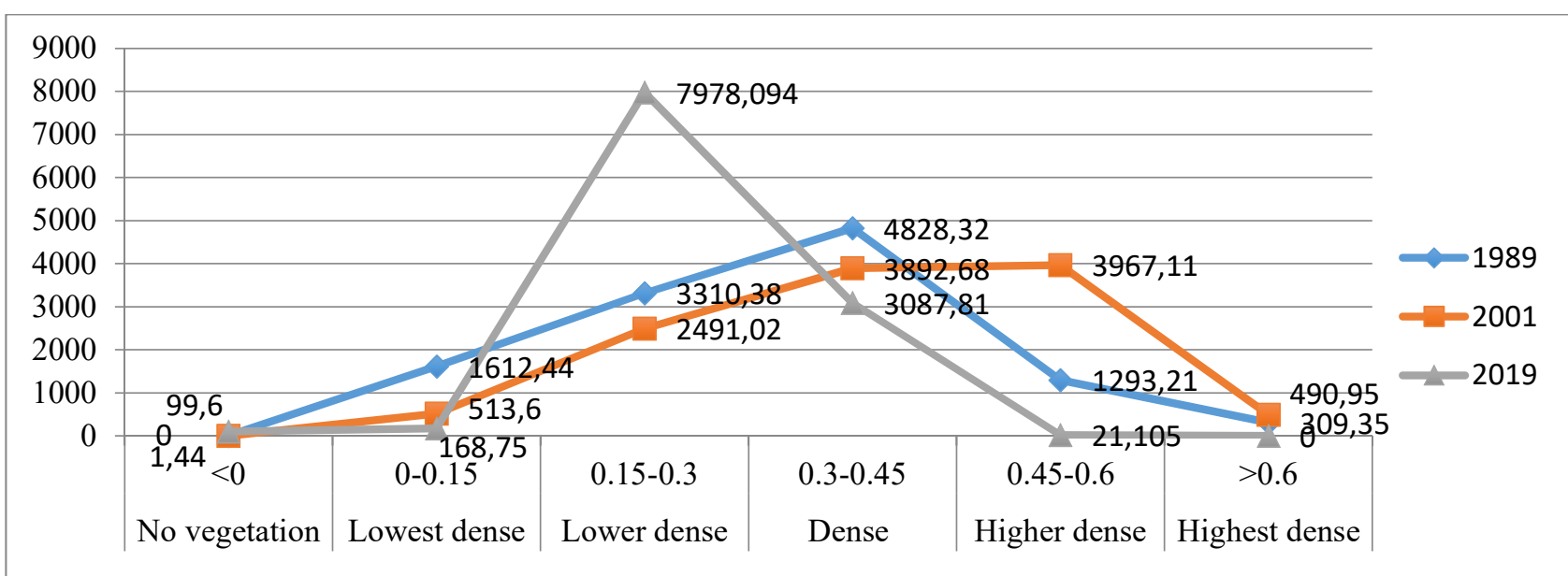

Figure 5: Categories of NDVI values in 1989, 2001 and 2019.

Change Detection in the Study Area

According to Holme et al. (1987), healthy vegetation absorbs most visible light and reflects large portion of the near infrared light. Contrary to this, if vegetation is unhealthy and sparse, the reflection of visible light will be more; while near infrared light reflection will be lesser. Bare soil, on the other hand, reflects both red and infrared portions of the electromagnetic spectrum 
moderately. In figure 4, changes of NDVI values of 1989, 2001 and 2019 were presented and showed that there is a decrease in greenness value of the study area.

In 1989 , the minimum value was -0.1 and maximum value was 0.69 with mean value of 0.29 and standard deviation of 0.23 . Similarly, in 2001 minimum and maximum values were 0 and 0.74 respectively. And their mean value was 0.37 while standard deviation was 0.22 . Moreover, in 2019, minimum, maximum, mean and standard deviation of NDVI values of the study area were $0.03,0.54,0.29$ and 0.15 respectively. Standard deviations of 1989, 2001 and 2019 were $0.23,0.22$ and 0.15 respectively (Table 4). Hence, the standard deviation result clearly showed that there was decline in vegetation cover.

In particular, the more dense vegetation were found to be high in 2001(8350.74 ha) compared to 1989 (6430.88 ha) and 2019 (3108.915 ha). Contrary to this, 2019 was Table 5: Change matrix of 1989-2001 characterized by high proportion of low and no vegetation (8246.44 ha) but in 2001 and 1989 it was 3004.62 and 4924.26 hectares (Figure 5). Therefore, the NDVI values clearly depicted a decline in vegetation cover in 2019 compared to its earlier years.

On the other hand, to detect changes of land use land cover classes' image differencing was used. Macleod and Congalton (1998) performed image differencing by subtracting the digital numbers (DN) value of one date for a given band from the $\mathrm{DN}$ value of the same pixel for the same band of another date. According to table 5, vegetation cover that was classified as afro-alpine and sub-afro-alpine was converted 'from' and 'to' these classes. Between 1989 and 2001, afro-alpine vegetation lost 578.91 ha and 355.44 ha were converted to afroalpine and sub-afroalpine vegetation. This showed that 223.47 hectares of afro-alpine and sub-afro-alpine has been converted to other land use land cover.

\begin{tabular}{|c|c|c|c|c|c|c|c|c|}
\hline \multirow{2}{*}{ Classe } & & \multicolumn{7}{|c|}{ Initial state of LULC (1989) } \\
\hline & & UAV & AV & Sw & GFO & $\mathrm{F}$ & $\mathrm{St}$ & Total \\
\hline \multirow{7}{*}{ 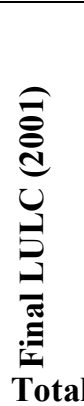 } & UAV & 1882.08 & 120.24 & 0.45 & 0.36 & 55.08 & 41.4 & 2099.61 \\
\hline & $\mathrm{AU}$ & 181.26 & 2606.28 & 7.02 & 3.33 & 289.71 & 453.23 & 3540.83 \\
\hline & Sw & 21.06 & 45 & 32.13 & 0.72 & 10.53 & 1.44 & 110.88 \\
\hline & GFO & 430.74 & 165.69 & 1.89 & 59.13 & 1017.3 & 325.8 & 2000.55 \\
\hline & $\mathrm{F}$ & 178.92 & 22.5 & 0.63 & 32.31 & 2004.66 & 376.47 & 2615.49 \\
\hline & St & 41.04 & 2.01 & 0.36 & 30.03 & 647.46 & 267.3 & 988.2 \\
\hline & & 2735.1 & 2961.72 & 42.48 & 125.88 & 4024.74 & 1465.64 & \\
\hline
\end{tabular}

UAV-Upper Afro-montane Vegetation; AV-Afro-alpine and sub-afroalpine vegetation; Sw-Swamps; GFO-Grazing/Fallow/Open areas; F-Farmlands; St-Settlement.

Table 6: Change matrix of 2001-2019

\begin{tabular}{|c|c|c|c|c|c|c|c|c|}
\hline \multirow{2}{*}{ Classes } & & \multicolumn{7}{|c|}{ Initial state of LULC (2001) } \\
\hline & & UAV & $\mathrm{AV}$ & Sw & $\mathrm{GFO}$ & $\mathrm{F}$ & St & Total \\
\hline \multirow{3}{*}{ בְּ } & UAV & 1789.16 & 44.7975 & 0.27 & 562.05 & 253.215 & 85.6125 & 2735 \\
\hline & AV & 132.547 & 1735.06 & 0.2475 & 896.85 & 76.005 & 121.005 & 2962 \\
\hline & Sw & 0.1575 & 2.565 & 17.0775 & 20.34 & 1.26 & 1.08 & 42.48 \\
\hline \multirow{4}{*}{ 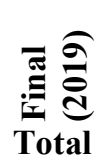 } & GFO & 2.565 & 0 & 0 & 53.5725 & 42.2775 & 12.465 & 110.9 \\
\hline & $\mathrm{F}$ & 129.533 & 15.1875 & 0.18 & 772.81 & 2069.93 & 993.6 & 3981 \\
\hline & Sw & 59.6475 & 49.365 & 0 & 421.808 & 555.818 & 378.967 & 1466 \\
\hline & & & 2113.61 & 1846.98 & 17.775 & 2727.4305 & 2998.51 & 1592.73 \\
\hline
\end{tabular}

UAV-Upper Afro-montane Vegetation; AV-Afro-alpine and sub-afroalpine vegetation; Sw-Swamps; GFO-Grazing/Fallow/Open areas; F-Farmlands; St-Settlement. Source: Authors 2019

Table 7: Commission, Omission, and producer and user accuracy (1989, 2001 and 2019)

\begin{tabular}{|c|c|c|c|c|c|c|c|c|c|c|c|c|}
\hline \multirow{3}{*}{$\begin{array}{l}\text { Classified } \\
\text { data }\end{array}$} & \multicolumn{12}{|c|}{ Percentage of } \\
\hline & \multicolumn{3}{|l|}{ Commission } & \multicolumn{3}{|c|}{ Omission } & \multicolumn{3}{|c|}{ Producer accuracy } & \multicolumn{3}{|c|}{ User accuracy } \\
\hline & 1989 & 2001 & 2019 & 1989 & 2001 & 2019 & 1989 & 2001 & 2019 & 1989 & 2001 & 2019 \\
\hline UAV & 1.1 & 23.4 & 9.26 & 0 & 1.67 & 1.01 & 100 & 98.3 & 98.9 & 98.9 & 76.6 & 97.7 \\
\hline $\mathbf{A V}$ & 2.73 & 5.88 & 0 & 0.93 & 2.44 & 0 & 99.1 & 97.6 & 100 & 97.3 & 94.1 & 100 \\
\hline GFO & 1.43 & 1.58 & 0 & 13.8 & 48.8 & 6.67 & 86.3 & 51.2 & 93.3 & 98.6 & 98.4 & 100 \\
\hline Sw & 20 & 0 & 2.27 & 0 & 0 & 14 & 100 & 100 & 86 & 80 & 100 & 97.7 \\
\hline St & 0 & 0 & 7.62 & 5.62 & 3.45 & 3 & 94.4 & 95.6 & 97 & 100 & 100 & 92.4 \\
\hline $\mathbf{F}$ & 7.43 & 22.2 & 1.23 & 0 & 1.18 & 2.44 & 100 & 98.8 & 97.6 & 92.6 & 77.8 & 98.8 \\
\hline
\end{tabular}

Where: UAV-Upper Afro-montane Vegetation; AV-Afro-alpine and sub-afroalpine vegetation; Sw-Swamps; GFOGrazing/Fallow/Open areas; F-Farmlands; St-Settlement. 
Between 2001 and 2019, 1114.74 and 111.95 hectares of afro-alpine and sub-afro-alpine vegetation class were converted 'to' and 'from' other land use land cover class respectively (see table 6). During this time, 1002.79 hectares have been converted.

\section{Accuracy Assessment}

Relatively, higher producer and user accuracy were ensured during classification (Table 7). The overall accuracy and Kappa coefficient results of the 1989, 2001 and 2019 were also fit well (Table 8). Specifically, Kappa coefficient result can be labeled as almost perfect agreement.

Table 8: Overall accuracy and Kappa coefficient (1989, 2001 and 2019)

\begin{tabular}{llll}
\hline & $\mathbf{1 9 8 9}$ & $\mathbf{2 0 0 1}$ & $\mathbf{2 0 1 9}$ \\
\hline Overall accuracy & 0.9648 & 0.8619 & 0.9566 \\
Kappa coefficient & 0.9566 & 0.8274 & 0.9464 \\
\hline
\end{tabular}

Table 9: Patch metrics of afro-alpine and sub-afro-alpine vegetation area

\begin{tabular}{l|llll|llll}
\hline \multirow{2}{*}{ Year } & \multicolumn{3}{|l|}{ Patch Area (in hectares) } & \multicolumn{4}{l}{ Perimeter (in kilometers) } \\
\cline { 2 - 9 } & Min. & Max. & Mean & Total & Min. & Max. & Mean & Total \\
\hline $\mathbf{1 9 8 9}$ & 0.09 & 3215.79 & 6.48 & 3540.63 & 0.12 & 276.16 & 0.85 & 460.08 \\
$\mathbf{2 0 0 1}$ & 0.09 & 2666.97 & 3.35 & 2951.72 & 0.12 & 276.18 & 0.57 & 507.18 \\
$\mathbf{2 0 1 9}$ & 0.02 & 1587.89 & 4.9 & 1846.98 & 0.02 & 228.87 & 0.89 & 335.61 \\
\hline
\end{tabular}

Table 10: Shape metrics of afro-alpine and sub-afro-alpine vegetation areas

\begin{tabular}{llll}
\hline Measures & $\mathbf{1 9 8 9}$ & $\mathbf{2 0 0 1}$ & $\mathbf{2 0 1 9}$ \\
\hline Shape index & 19.33 & 23.3 & 19.52 \\
Fractal dimension index & 1.03 & 1.03 & 1.04 \\
\hline
\end{tabular}

Table 11: Class metrics of afro-alpine and sub-afro-alpine vegetation area

\begin{tabular}{llll}
\hline Year & Total edge $(\mathbf{K M})$ & Edge density $\mathbf{( m / h a )}$ & Largest patch index $\mathbf{( \% )}$ \\
\hline $\mathbf{1 9 8 9}$ & 460.08 & 24.316 & 16.996 \\
$\mathbf{2 0 0 1}$ & 507.18 & 26.805 & 14.095 \\
$\mathbf{2 0 1 9}$ & 335.61 & 17.724 & 8.3858 \\
\hline
\end{tabular}

Table 12: Aggregation metrics of afro-alpine and sub-afro-alpine vegetation area

\begin{tabular}{lllllll}
\hline Year & NP & PD & PLADJ & IJI & SPLIT & AI \\
\hline $\mathbf{1 9 8 9}$ & 544 & 2.8751 & 90.213 & 73.86 & 34.61 & 90.67 \\
$\mathbf{2 0 0 1}$ & 884 & 4.6721 & 87.157 & 69.32 & 50.32 & 87.64 \\
$\mathbf{2 0 1 9}$ & 377 & 1.991 & 93.186 & 41.26 & 140.69 & 93.51 \\
\hline
\end{tabular}

\section{Fragmentation Analysis}

As indicated in table 9, there were decreased maximum and minimum patch area from year 1989 to 2019. Perimeters of patches were also diminished from over the same years. It was clearly observed that there were decrease in afro-alpine and sub-afro-alpine class total patch area and perimeter in 2019 compared to initial year.

As indicated in table 10, shape index of afro-alpine and sub-afro-alpine vegetation areas showed oscillating trend and shows higher values which indicated some shape complexity. On the other hand, fractal dimension index increases slightly with passage of time that showed absence of shape complexity.

Tables 11 showed that in the year 2019, there were greater ups and down of area, total edge and edge density of afro-alpine and sub-afro-alpine vegetation. In terms of largest patch index, afro-alpine vegetation decreased from 1989 to 2019.
Aggregation describes dispersion, interspersion, subdivision and isolation. In this paper, number of patches (NP), patch density (PD), percentage of like adjacencies (PLADJ), interspersion and juxtaposition index (IJI), splitting index (SPLIT) and aggregation index (AI). As indicated in table 12, NP, PD, SPLIT and IJI were manifested higher values that indicate the existence fragmentation. On the other hand, PLADJ and AI showed value approaching to 100 . But, since the values are not exactly 100 it is an indication of existence of some fragmentation.

\section{Discussion}

Standard deviation result of NDVI values declined from 0.23 (in 1989) to 0.22 (in 2001) and 0.15 (in 2019) and depicted that there is a decreasing trend of greenness of the study area. Likewise, the areas covered by dense vegetation in 2019 go down to 3109.92 hectares compared to initial time (1989). This shows that degradation of areas was increased and vegetation cover in the Gugu Mountain Ranges was destructed. Similar to 
this finding, Alatorre and Begueria (2010) used NDVI to analyze vegetated and degraded areas and concluded that results were spatially consistent and coincided with the spatial distribution of land use land cover. Moreover, NDVI values of the same study showed that there was also decrease in swampy areas from 1989 to 2019 in which negative values were not observed in recent years. Anand et al. (2018) confirmed that the smaller (below zero) values showed barren lands, snow, rocks and sand.

Using land use land cover analysis result, in the past thirty years, afro-alpine and sub-afro-alpine ecosystem of GMR has been diminished from 3540.63 ha (in 1989) to 1846.98 ha (in 2019). But, the rate of change was not significantly consistent among years. The rate of change was estimated at about $1.49 \%$ between 1989 and 2001, and $2.62 \%$ between 2001 and 2019. This result implies that the rate of habitat conversion was increased to the level that it could facilitate speedy depletion and degradation. In line with this, Institute of Biodiversity Conservation (2005) indicated that the rate of change to be very alarming resulting in the reduction of the original species richness of afro-alpine and subafroalpine environments and restricted to scattered areas that are not easily accessible.

The result showed that patches area and perimeter of patches of current time (2019) was declined compared to initial year (1989). This could affect biodiversity in the study area negatively since fragmentation can also be linked with patch size (Jaybhaye et al. 2016) and its effect depends up on size of the resulting fragments (Fuller et al., 2015). Shape index result depicted some complexity where as fractal dimension result did not assure shape complexity since its value approaches to one. Simpler shapes allow higher survival of population. Ragub and Bagarina (2012) agreed that increased complexity of shape increased likelihood of contact between interior and edge species. But, it is the interplay between size and shape that determines the survival of population dynamics (Alharbi and Petroskii 2016, LaGro 1991). Lesser fragmentation result of shape indexes cannot be assured suitability of habitat for afro-alpine and sub-afro-alpine biodiversity. In their study of tropical forest fragments, Hill and Curran (2003) accounted area, shape and isolation for sharply decreasing of variability of species diversity.

The results of total edge and edge density higher values with slight decrease, and largest patch index values were smaller with decreasing trend. This implied the presence of fragmentation. According to Liu et al. (2017), the higher the value of edge density the greater fragmentation it shows. Similarly, Jaybhaye et al. (2016) reported that decrease in largest patch density as an indicator of fragmentation. To this effect, largest patch index result of afro-alpine class was declined from $16.99 \%$ (in 1989) to $14.1 \%$ (in 2001) and to $8.4 \%$ (in 2019). Consequently, they indicated as decrease in largest patch size happens due to increase in density of small patch as already seen in this study, that is, 544 in 1989, 884 in 2001 and 377 in 2019.
Patch density was also more than zero that showed presence of fragmentation. Percentages of like adjacencies result were approaching to maximal value, but not 100, showing that there were contagious distribution. Interspersion and juxtaposition index result of the 1989, 2001 and 2019 approaches to 100 depicted that a patch is equally adjacent to all other patch types. Splitting index value showed as focal patch type were reduced and subdivided into smaller patches. Aggregation index also indicated that the presence of disaggregation of afro-alpine and sub-afro-alpine class.

It is not only loss that is problem for wild plants and animals but also the degree of fragmentation of their habitat (Food and Agricultural Organization 2002). Thus, Gugu Mountain Ranges afro-alpine and sub-afroalpine environments were characterized by disaggregation patches that range from slight to high level. Almost all computed parameters of fragmentation showed that the presence of disaggregation. Even though effects of fragmentation depends drivers of fragmentation, time it takes, agents of fragmentation, size of resulting fragments and type of species (Fuller et al. 2015), it causes population losses and affects habitat quality (Flaspohler et al. 2010, Broadbent et al. 2008).

Based on the land use land cover analysis result, expansion of grazing land, farmland and settlement were taken as disturbances that cause fragmentation. That is, between 1989 to 2001 afro-alpine and sub-afro-alpine class was converted to settlement (453.23 ha), farmland (289.71 ha) and grazing land (3.33 ha). Correspondingly, between 2001 and 2019, it was converted to grazing land (896.85 ha), settlement (121.005 ha) and farmland respectively. In line with this, various studies showed that loss of biodiversity can be resulted by land use changes which are driven by anthropogenic activities (Teillard et al. 2016, Mutia 2009, Raghubanshi and Tripathi 2009, Gaston and Spicer 2004; Murthy et al. 2003).

\section{Conclusion}

The total area of afro-alpine and sub-afro-alpine of Gugu Mountain Ranges comes across a decreasing trend over the last 30 years. Change detection values showed tremendous conversions of land uses land cover toward settlement, grazing and farm plots. These land class contributed toward habitat loss and fragmentation. Higher fragmentations facilitated over exploitation of the biodiversity reserves and losing of small fragments. Therefore, the growing of habitat into patches and shrinking of these patches further into smaller and smaller up to a complete damage was triggered by settlement, grazing and farming activities undertaken in the study area. Hence, we urge Oromia Regional government to take appropriate conservation measures.

\section{Acknowledgements}

We are indebted to appreciate Jimma University and officials at district and kebele level of the study area for their unreserved cooperation. 


\section{Conflict of interest}

There is no conflict of interest

\section{References}

Alatorre L. C. and Begueria S. (2010). Analysis of spatial and temporal evolution of the NDVI on vegetated and degraded areas in the central Spanish Pyrenees. In Wegner W., Szwekely, B. (eds): ISPRS TC VII symposium -100 years ISPRS, Vienna, Austria, July 5-7, 2010, IAPRS, vol. XXXVIII, part 7A.

Anand A., Singh S. K. and Kanga S. (2018). Estimating the change in forest cover density and predicting NDVI for west Singh hum using linear regression. Intern. Journ. For Environmental Rehabilitation and Conservation, IX (1): 193-203.

Badege B. (2001). Deforestations and Land Degradation in Ethiopian Highlands. A Strategy for Physical Recovery. Journal of East African Studies. 8 (1): 726.

Broadbent E. N., Asner G. P., Keller M., Knapp D. E., Oliveira P. J. C. and Silva J. N. (2008). Forest fragmentation and edge effects from deforestation and selective logging in the Brazilian Amazon. Biological conservation, 141, 1745-1757.

Ethiopia Biodiversity Institute (2014). Ethiopia's fifth national report to the convention on biological diversity. Addis Ababa, Ethiopia.

Ethiopia Biodiversity Institute (2015). Ethiopia's national biodiversity strategy and action plan 20152020. Addis Ababa, Ethiopia.

Ethiopian Panel on Climate Change (2015). First Assessment Report, Working Group II Biodiversity and Ecosystems. Ethiopian Academy of Sciences, Addis Ababa.

Fahrig L. (2003). Effects of habitat fragmentation on the biodiversity. Annu. Rev. ecol. Evol., 34, 487-515. Doi.10.1146/annrev.ecosy.34.011802.132419.

Fahrig L. (2017). Ecological responses to habitat fragmentation per se. annu. Rev. Eco. Evo. Syst., 48, $1-23$.

Flaspohler D. J., Guardina C. P., Asner G. P., Hart P., Price J., Lyons C. K., and Castaned X. (2010). Long term effects of fragmentation and fragment properties on bird species richness in Hawaiian forests. Biological conservation, 143, 280-288. DOI.10.1016/j.biocon.2009.10.009.

Fletcher R. J., Didham R. K., Banks-Leite C., Barlow J., Ewers R. M., et al. (2018). Is habitat fragmentation good for biodiversity? Biological conservation, 226, 9-15.

Food and Agriculture Organization (2002). Current issues in biodiversity conservation. Wild life management. Working paper, no. 4. Rome, Italy.

Foody G. M. (2008). GIS: Biodiversity applications: Progress report. Progress in physical geography, 32(2), 223-235.

Franklin A. B., Noon B. R. and George T. L. (2002). 'What is habitat fragmentation?' In T. L. George and D. S. Dobkin (eds), Effects of habitat fragmentation on birds in western landscapes: contrasts with paradigms from the eastern united states. Studies in Avian Biology, 25, 20-29.

Fuller M. R., Doyle M. W. and Strayer D. L. (2015). Causes and consequences of habitat fragmentation in river networks. Ann. N. Y. Acad Sci., 1355, 31-51. Doi.10.1111/nyas.12853.

Gaston K. J. and Spicer J. L. (2004). Biodiversity: an introduction. $2^{\text {nd }}$ ed. Blackwell science ltd.

Gazioğlu, C. (2018). Biodiversity, Coastal Protection, Promotion and Applicability Investigation of the Ocean Health Index for Turkish Seas. International Journal of Environment and Geoinformatics (IJEGEO), 5(3), 353-367.

Gorji, T., Yıldırım, A., Sertel, E., Tanık, A. (2019). Remote sensing approaches and mapping methods for monitoring soil salinity under different climate regimes, International Journal of Environment and Geoinformatics (IJEGEO), 6(1), 33-49.

Hill J. L. and Curran P. J. (2003). Area, shape and isolation of tropical forest fragments: effects on tree species diversity and implications for conservation. Journal of biogeography, 30, 1391-1403.

Holme A. R., Burnside D. G. and Mitchell A. A. (1987). The development of a system for monitoring trend in the range condition in the arid shrub lands of western Australia. Australian range journal, 9, 1420.

Hurni H. (1995). Ethiopia: Agro-ecological belts, three map sheets, scale 1:1,000,000. Ministry of Agriculture, Ethiopia and Centre for Development and Environment, Berne.

Hurni H., Abate S., Bantider A., Debele B., Ludi E., Portner B., Yitaferu B. and Zeleke G. (2010). Land degradation and sustainable land management in the Highlands of Ethiopia.In: Hurni H, Wiesmann U, editors; with an international group of co-editors. Global Change and Sustainable Development: A Synthesis of Regional Experiences from Research Partnerships. Perspectives of the Swiss National Centre of Competence in Research (NCCR) NorthSouth, University of Bern, Vol. 5. Bern, Switzerland: Geographica Bernensia, pp 187-207.

Ibanez T., Hequet V., Chambrey C., Jaffre T. and Birnbaum P. (2017). How does forest fragmentation affect tree communities? A critical case study in the biodiversity hotspot of new Caledonia. Landscape ecol, doi.10.1007/s10980-017-0534-7.

Institute of Biodiversity Conservation (2005). National biodiversity strategy and action plan. Addis Ababa, Ethiopia.

Institute of Biodiversity Conservation (2012). Country report submitted to $\mathrm{FAO}$ on the state genetic resources of Ethiopia. Addis Ababa, Ethiopia.

Jaybhaye R. G., Kale P. K. and Joshi P. (2016). The relevance of geospatial techniques in the assessment of forest fragmentation of anjaneri hill, Nasik distric, Maharashtra, India. Journal of environmental science, toxicology and food technology, 10 (4): 1-10. Doi.10.9790/24021004010110.

Kedirkan, N. (2019). Water surface Changes of Lakes in the Central Rift Valley of Ethiopia, International 
Journal of Environment and Geoinformatics 6 (3), 264-267.

LaGro J. (1991). Assessing patch shape in landscape mosaics. Photogrammetric engineering and remote sensing, 57 (3): 285-293.

Liu S., Wang D., Li H., Li W. and Wang Q. (2017). Ecological land fragmentation evaluation and dynamics change of a typical black soil farming area in Northeast china. Sustainability, 9 (300): 1-21. DOI.10.3390/su9020300.

Macleod R. D. and Congalton R. G. (1998). A quantitative comparison of change detection algorithms for monitoring Eelgrass from remote sensed data. Photogrammetric engineering and remote sensing, 64(3): 207-216.

Malczewski J. (1999). GIS and Multicriteria Decision Analysis. John Wiley and Sons, Inc., Canada.

Michelsen O. and Lindner J. P. (2015). Why include impacts on biodiversity from land use in LCIA and how to select useful indicators? Sustainability, 7, 6278-6302.

Minu S. and Shetty A. (2015). A comparative study of image change detection algorithms in MATLAB. Aquatic procedia, 4, 1366-1373.

Munir T., Malik M. F., Naseem S. and Azzam A. (2018). Habitat fragmentation- a menace of biodiversity: A review. International Journal of Fauna and Biological Studies, 5 (4):37-41.

Murthy M. S. R., Giriraj A. and Dutt C. B. S. (2003). Geoinformatics for biodiversity assessment. BIOL. LETT. 40(2): 75.100

Mutia T. M. (2009). Biodiversity conservation.Presented at short course IV on exploration for geothermal resources, organized by UNU-GTP, KenGen and GDC, at Lake Naivasha, Kenya, Nov. 1-22.

Puyravaud J. (2003). Standardizing the calculation of annual rate of deforestation. Forest ecology and management, 177, 593-596.

Raghubanshi A. S. and Triparthi A. (2009). Effects of disturbance, habitat fragmentation and alien invasive plants on floral diversity in dry tropical forests of Vindhyan: a review. Tropical ecology, 50 (1): 5769.

Ragub J. O. and Bagarina R. T. (2012). Fractal dimension and patchiness in Hinabian-Lawigan watershed southern leyte, Philipines. IAMURE International Journal of Ecology and Conservation, 4, 17-33.

Rees W. G. (2001). Physical principles of remote sensing. $2^{\text {nd }}$ ed. Cambridge university press, Cambridge.

Roy A. and Srivasta V. K. (2012). Geospatial approach to identification of potential hotspots of landuse and land cover change for biodiversity conservation. Current science, 103 (8), 1174-1180.

Roy P. S. (2011). Geospatial characterization of biodiversity: need and challenges. International Archives of the Photogrammetry, Remote Sensing and Spatial Information Sciences, Volume XXXVIII-8/W20, 2011 ISPRS Bhopal 2011 Workshop, 8 November 2011, Bhopal, India
Roy P. S. and Behera M. D. (2002). Biodiversity assessment at landscape level. Tropical Ecology 43(1): 151-171, 2002.

Roy P. S. and Roy A. (2010). Land use and land cover change in India. A remote sensing and GIS perspective. Journal of the Indian institute of science, 90 (4): 489-501.

Roy P.S. and Tomar S. (2000). Biodiversity characterization at landscape level using geospatial modeling technique. Biological Conservation, 95: 95-109.

Salem B. B. (2003). Application of GIS to biodiversity monitoring. Journal of arid environments, 54: 91114.

Solomon C. and Dereje T. (2015).Threats of biodiversity conservation and ecotourism activities in Nechsar National Park, Ethiopia. International journal of biodiversity and conservation, 7(2), 130-139.

Tchouto M.G.P., Yemefack M., De Boer W.F., De Wilde J.J.F.E., Van der Maesen L.J.G., Cleef A.M. (2006). Biodiversity hotspots and conservation priorities in the Campo-Ma'an rain forests, Cameroon. Biodiversity and Conservation, 15, 1219-1252.

Teillard F., Anton A., Dumont B., Finn J. A., Henry B., Souza D. M., Manzano P. et al. (2016). A review of indicators and methods to assess biodiversity: Application to livestock production at global scale. Livestock environmental assessment and performance (LEAP) partnership. FAO, Rome, Italy.

Viera, A. J. and Garrett, J. M. (2005). Understanding inter observer agreement: The Kappa statistic. Research series, 37 (5): 360-363.

Wan H. Y., Cushman S. A. and Ganey J. I. (2018). Habitat fragmentation reduces genetic diversity and connectivity of the Mexican spotted owl: A simulation study using empirical resistance models. Genes, 9 (403):1-21. Doi.10.3390/genes9080403.

Wang X., Blanchet F. G. and Koper N. (2014). Measuring habitat fragmentation: an evaluation of landscape pattern metrics. Methods in ecology and evolution, 5, 634-646. Doi.10.111/2041-210x.12198

Woldeamlak B. (2002). Land Cover Dynamics since 1950s in Chemoga Watershed, Blue Nile Basin, Ethiopia. Mountain Research and Development 22(3): 263-269.

Zaitunah A., Samsuri, Ahmad A. G. and Safitri R. A. (2018). Normalized difference vegetation index (NDVI) analysis for land cover types using landsat 8 OLI in besitang watershed, Indonesia.IOP conf. series. Earth and Environmental Science, 126, 012112. Doi:10.1088/1755-1315/126/1/012112. 